\title{
統計的グリーン関数法による強震動予測法の検証と 仮想福岡地震への適用 \\ CALIBRATION OF STRONG MOTION PREDICTION METHOD USING STATISTICAL GREEN'S FUNCTION AND ITS APPLICATION TO HYPOTHESIZED FUKUOKA EARTHQUAKE
}

\author{
伊 藤 茂 郎*, 川瀬＼cjkstart博** \\ Shigeo ITOH and Hiroshi KAWASE
}

\begin{abstract}
In our previous work we extracted statistical characteristics of seismic ground motions from K-net records of 25 earthquakes observed at 142 stations in the Kyushu region in order to establish the synthesis method of statistical Green's functions. In this paper we study the strong motion prediction method using these statistical Green's functions. First, we apply this method to the Kagoshima-ken Hokuseibu earthquake of March 26, 1997 and compare the synthetics with the observed. Second, we simulate strong motions at the bedrock level during the Hyogo-ken Nanbu earthquake of 1995. Synthetic waveforms based on this method match quite well with the observed. Thus it is proved that we can predict the bedrock motions using our statistical Green's function if we properly express the source model. Finally we applied this method to predict strong motions in Fukuoka City for a hypothesized Fukuoka earthquake. First strong motions at the bedrock level are predicted and then the strong motions at the ground surface are obtained by the 1-D wave propagation theory. The peak ground velocity thus estimated reaches $100 \mathrm{~cm} / \mathrm{s}$, which is less than Kobe.
\end{abstract}

Keywords : strong motion prediction, Green's function, statistical characteristics of ground motion, bedrock, surface geology 強震動予測，グリーン関数，統計的地震動特性，基盤，表層地盤

\section{1.はじめに}

現在では構造物の耐震設計を行う際に地震応答解析を行う機会が 多いが、建設サイトの地震動特性を十分考虑した入力地震動が用い られているとは言い難く、いまだ特定の強震記録を補正した波形や 回帰分析に基づく応答スペクトルから得られる模擬地震動を使用し ている状況にある。しかし、兵庫県南部地震において注目された、 いわゆる「震災の帯」は、断層の破壊伝播によるディレクティビテ イ効果や大阪盆地の深い地盤構造による増幅効果で生じたものであ り 1)、震源およびサイトの特性を十分考虑した入力地震動を用いる ことの重要性が浮き彫りになった。近年、地震のスケーリング則に 基づいて中小地震の観測記録を多数重ね合わせる経験的グリーン関 数法が、強震動予測手法として注目されその有効性が検証されてい る例えは2 2)。この手法は、従来の経験的手法では考虑できない震源過 程を表現でき、また理論的手法において問題となる短周期領域まで 地盤構造を直接知ることなく、強震動を予測することができる。し かし、中小地震記録を用いる場合、記録がないと波形合成できない ことから、それにかえて多数の中小地震記録を統計解析し、その平 均的特性を有する中小地震相当の波形を用いる統計的グリーン関数 法が最近提案され予測に用いられるようになってきている。このう ち、釜江ら ${ }^{3)}$ は震源スペクトルを $\omega^{-2}$ モデル ${ }^{4)}$ とした Boore のモデル 5)を用いて作成される統計的地震動をグリーン関数として、地域的
特性を反映した強震動予測手法を提案した。同様な手法は壇ら ${ }^{6)}$ も 関東地震の評価に用いている。ただ Boore のグリーン関数は観測記 録の統計值というよりも理念的なものである。これに対し佐藤ら 7$)$ は、ボアホール観測記録を用いて推定された工学的基盤波から、地 震動の経時特性 ${ }^{8)}$ と $\omega^{-2}$ モデルによるスペクトル特性 ${ }^{9)}$ をそれぞれ 別個に評価し、作成された統計的グリーン関数を波形合成して 1978 年宮城県沖地震による仙台での地震動を推定した。さらに表層地盤 の非線形性を考虑して地表地震動を評価し、その妥当性を検証した。

最近筆者ら ${ }^{10)}{ }^{11}$ ( は科学技術庁防災科研の強震観測網 K-net の九州 地方 142 地点、25 地震の観測記録 $(1,278 \times 2$ 波) から二段階回䚻分 析手法を用いて中小地震の統計的経時特性とスペクトル特性を抽出 した。ここで重要なことは、経時特性とスペクトル特性が同じデー タから同じマグニチュード M と震源距離 $\mathrm{X}$ の関数として統一的にモ デル化されていることである。また、九州地方の K-net 観測点ほと んど全てについて統計的特性が得られているので、マグニチュード と震源距離さえ指定すれば、任意の K-net サイトで統計的グリーン 関数を作成できるのみならず、S 波速度約 $1 \mathrm{~km} / \mathrm{sec}$ の露頭岩盤と見 なせる基準観測点の統計的性質を用いて九州地方の任意地点で基盤 面上のグリーン関数の作成が可能となっている。

そこで本論文では、この統計的グリーン関数法の有用性を示し、 それを仮想福岡地震に適用して予測結果を求め考察する。まず 1997
* 清水建設 工修

(元九州大学 大学院生)

** 九州大学大学院人間環境学研究院 教授·工博
Shimizu Corporation, M. Eng.

Prof., Faculty of Human-Environment Studies, Kyushu Univ., Dr. Eng. 
年 3 月 26 日に発生した鹿児島県北西部地震の再現を行い、提案手法 の有用性を確認する。ここでは本震直後に発生した余震と同じ規模 の統計的グリーン関数を作成し、断層モデルを用いて波形合成する。 比較のため、余震記録を用いた経験的グリーン関数法や従来型の経 験的手法によるシミュレーションも行う。次に、基盤における統計 的グリーン関数を用いて 1995 年の兵庫县南部地震の強震動シミュ レーションを行う。ここでは破壊開始点を変化させたパラメトリッ クスタディを行い、基盤面最大速度分布がどのように変化するかに ついて考察するとともに、露頭岩盤と見なせる神戸大学 $(\mathrm{KBU})$ や本山 第一小学校 (MOT)の観測記録と本震と同じ破壊開始点を用いた再現 波を比較する。これにより基盤上の地震波の再現性を検証する。そ して最後に、福岡市直下の警固断層に兵庫県南部地震の断層モデル を適用し、仮想福岡地震の強震動予測を行う。本研究では福岡市の 町丁目ごとの強震動予測を行うために、まず基盤面における強震動 を求め、次に各町丁目ごとの地盤特性を考慮して地表面の強震動を 予測するという二段階の手法を用いている。本論文の強震動予測プ ロセスを用いることにより中小地震の観測記録が得られていない地 点でも予測が可能となる。なお本研究で対象とする周波数は、統計 的デー夕解析の際の有効周波数 $0.1 \sim 10 \mathrm{~Hz}$ から、小地震の長周期域 のノイズに配虑してさらに限定し、0.2 10Hz とする。

\section{2. 統計的グリーン関数の作成}

統計的グリーン関数は、筆者らが提案している統計的経時特性 ${ }^{10)}$ と統計的スペクトル特性 ${ }^{11}$ を用いて作成する。これら 2 つの地震動 特性は、九州地方の K-net 観測点 142 地点で観測された 25 地震の加 速度波形のS 波主要動部から抽出した。用いたデータは気象庁マグ ニチュードMj が 4.5〜6.6、震源距離 X が約 15〜300km のもので、 1,278×2 成分 (NS, EW) である。図 1 に用いた地震の震源と観測点を 示す。データは、まず日本付近の平均的な $\mathrm{S}$ 波の走時を用いて $\mathrm{S}$ 波 初動以降 60 秒間を切り出し、前後に:2 秒のコサインテーパをつけ 64 秒間のデータにした。S 波初動以降がうまく切り出されていない 場合は目視による切り出しを行っている。スペクトルの分離を行う 際に必要な基準観測点 MYZ005 についてはあらかじめ、K-net の地盤 情報から一次元重複反射理論を用いて表層 $(4 \mathrm{~m})$ の影響をはぎ取り、 その基盤波を推定した。このような処理を行うことにより当該地点 はS 波速度 $1 \mathrm{~km} / \mathrm{sec}$ の露頭岩盤上の観測点と見なすことができる。

統計的経時特性は、Boor $\mathrm{e}^{5)}$ の包絡線関数W(t) Boore のモデルは、継続時間 Td、振幅が最大となる時刻 Tr の Tdに

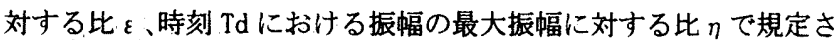
れる。(1) 式の $\mathrm{H}(\mathrm{t})$ は単位ステップ関数を表し、(2) 式のaは関数W(t) の最大値が 1 になるように表現されている。

$$
W(t)=a \cdot t^{b} \cdot \exp (-c t) \cdot H(t)
$$

$$
\begin{aligned}
& a=\left(\frac{2.7182}{\varepsilon \cdot T_{d}}\right)^{b} \\
& b=\frac{-\varepsilon \cdot \ln \eta}{[1+\varepsilon \cdot(\ln \varepsilon-1)]} \\
& c=\frac{b}{\varepsilon \cdot T_{d}}
\end{aligned}
$$

$\eta=0.1$ で固定した包絡線関数 $W(\mathrm{t})$ を観測記録にフィッティングさ

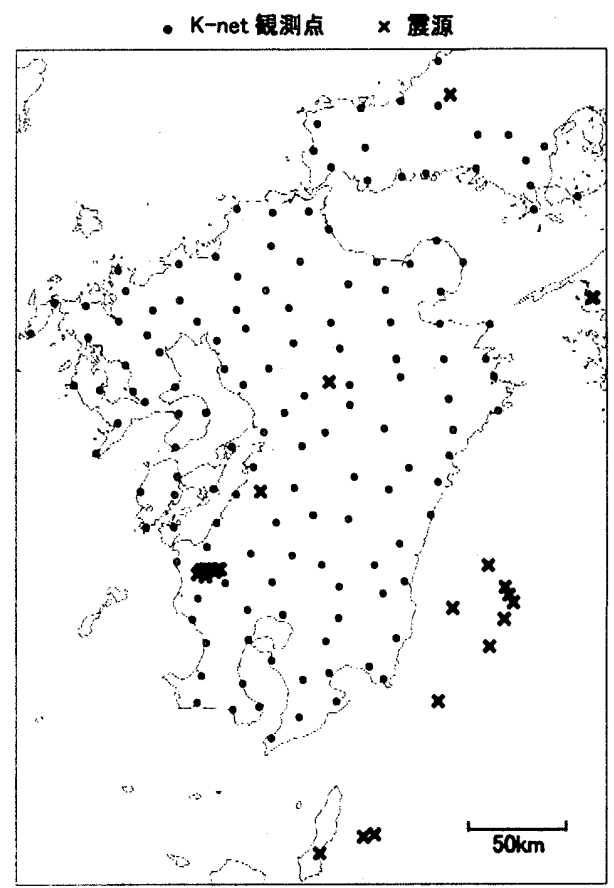

图 1 解析に用いた地震の震源と钼測点の位置
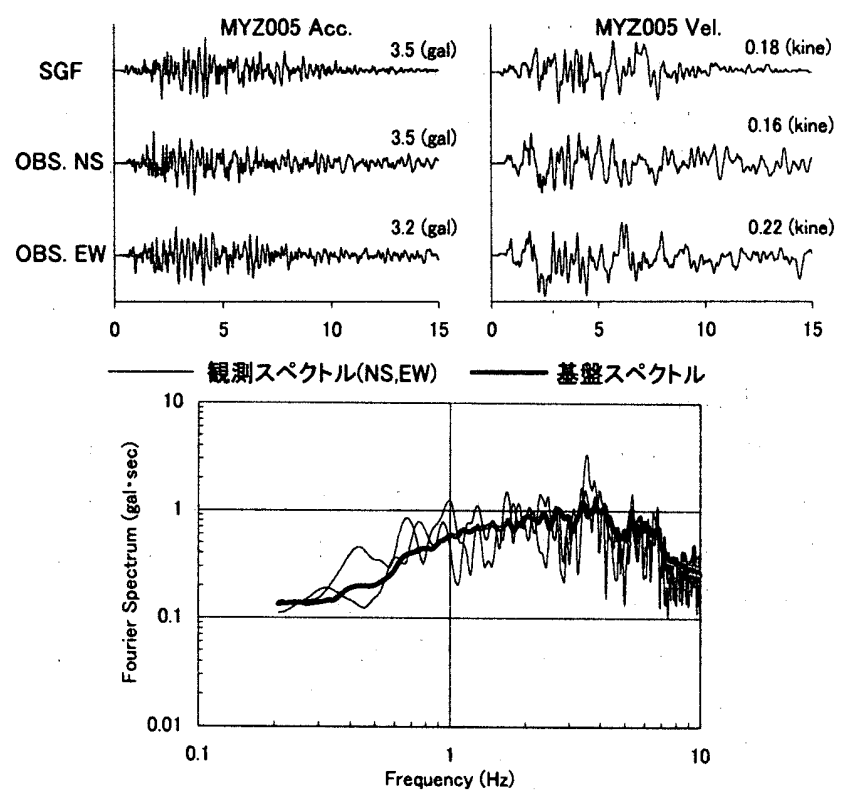

图 2 基盤スペクトルと基盤経時特性から得られる䋘計的グリーン関 数 (Mj=5.1，X=84km) と翻測記録 (1996.10.19 23:01 日向灘沖)の比較 せモデルパラメターTr $(=\varepsilon \times \mathrm{Td})$ と $\mathrm{Td}$ を同定し、得られた $\mathrm{Tr}$ と $\mathrm{Td}$ をマグニチュードM と震源距離 Xで回㷌する。ここではマグニチュ 一ドと震源距離に正の相関があることを防ぐため二段階回帰分析を 行っている。最終的に得られた回帰式は次式のように表される。

$\log \mathrm{T} r=0.0956 \cdot \mathrm{M}+0.3911 \cdot \log \mathrm{X}-0.6620$
$\log \mathrm{T} d=0.0925 \cdot \mathrm{M}+0.4367 \cdot \log \mathrm{X}-0.2890$

(5)，(6)式は、基準観測点(露頭岩盤上)とした MYZ005(日向)のもの である。右辺第三項が経時特性のサイト係数を表し、これを各観測 点のサイト係数に置き換えれば、Tr, Td が各観測点ごとに得られる。

統計的スペクトル特性 $\mathrm{F}(\mathrm{f})$ は、マグニチュードM と震源距離 X を用いて簡単に表現できる壇ら ${ }^{12)}$ の二段階回㷌分析手法を適用し

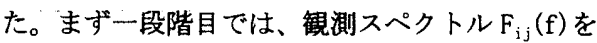

$$
\log F_{i j}(f)=S_{i}(f)-\log X_{i j}+b(f) \cdot X_{i j}+C_{j}(f)
$$


でモデル化する。i は地震番号、 $\mathrm{j}$ は锥測点番号を表し、 $\mathrm{S}_{\mathrm{i}}$ (f) は祳 源特性、 $b(f)$ は距離係数、 $C_{j}(f)$ は $j$ 観測点のサイト係数である。 $S_{i}(f)$ と $\mathrm{C}_{\mathrm{j}}(\mathrm{f})$ を分離するために基隻観測点 $(\mathrm{j}=1)$ のサイト保数について自 由地表面の拘束条件 $10^{\mathrm{Cl}(\mathrm{f})}=2.0$ を与えた。よって一段階目で得られ た $C_{j}(f)$ は基隻観測点に対する比として決まるので、基隻観測点は サイト増幅のない露頭岩盤であることが望ましい。次に二段階目で は (8)式のように震源特性をMの1次式でモデル化し、一段階目で得 られた距離係数 $\mathrm{b}(\mathrm{f})$ を用いて $\mathrm{a}(\mathrm{f})$ および $\mathrm{C}{ }_{\mathrm{j}}(\mathrm{f})$ を求める。

$\log F_{i j}(f)=a(f) \cdot M_{i}-\log X_{i j}+b(f) \cdot X_{i j}+C_{j}^{\prime}(f)$

以上により得られた経時特性とスペクトル特性を用いて統計的グ リーン関数を作成する。まず、マグニチュードM、震源距離 X およ び観測地点を設定し、経時特性については回㷌式(5)，(6)から得られ る Trと Td を用いて Boore の包絡線関数W(t) 計算する。スペクト ル特性については回㷌式(8)から目標フーリエスペクトル $F(f)$ を計 算する。次にランダム位相と目標スペクトル $\mathrm{F}(\mathrm{f})$ を用いて定常波を 作成し、包絡線関数 $W(t)$ を掛ける。この時点で、W $(\mathrm{t})$ を措けて得ら れた波形 $g(t)$ のフーリエスペクトルは目標スペクトル $F(f)$ より減 少しているので、g(t)をフーリエ変換し位相スペクトルは保存して、 スペクトル特性を目標フーリエスペクトル $\mathrm{F}(\mathrm{f})$ で置き換え、フーリ エ逆変換することにより統計的グリーン関数 $\mathrm{f}(\mathrm{t})$ を作成する。得ら れた統計的グリーン関数はスペクトル補正のため立ち上がりが広が り、一部が波形の後半にずれ込むので、時間軸を 5 秒間シフトさせ、 5 秒以降にコサインテーパを付けたウィンドウを施した。以上によ り、マグニチュードと震源距離を与えれば任意のサイトで個別の統 計的グリーン関数を作成でき、また基淮観測点の統計的性質は基盤 における地震動特性と見なせるので、基盤における波形合成用グリ ーン関数の作成が可能である。図 2 に基準観測点の基盤スペクトル と基盤経時特性を用いて作成した統計的グリーン関数 $(M j=5.1$, $X=84 \mathrm{~km})$ と観測記録 (1996.10.19 23:01 日向灘沖)を比較して示す。 最上段に示す統計的グリーン関数(SGF) と二段目、三段目の観測記録 (OBS. NS, OBS. EW) は包絡形・最大值とも良く一致している。但し、速 度波形については特に後半部において加速度波形ほど一致度は良く ない。これは加速度波形が包絡線の形状で拘束が効いているのに対 し、速度波形については直接的に拘束が効いていないことによるも ので、加速度包絡形とランダム位相を与える生成法を用いる限り避 けられないものと思われる。基盤スペクトルは観測スペクトルの NS, EW 成分の平均的な值となっている。

\section{3. 鹿児島県北西部地震の強震動シミュレーション}

\section{1 解析地点と断層パラメター}

次に統計的グリーン関数法を用いて 1997 年 3 月 26 日に発生した 鹿児島県北西部地震の強震動シミュレーションを行う。比較のため、 本震直後に発生した余震 (1997.03. $2617: 39 \mathrm{Mj}=4.7$ ) 記録を用いた経 験的グリーン関数法や従来型の経験的手法を用いたシミュレーショ ンも同時に行う。解析地点は震源断層を取り囲む KGS002 (出水), KGS004 (阿久根)，KGS005(宮之城)，KGS007(川内)の 4 地点である。

図 3 に震源断層と解析地点を示す。

従来型の経験的手法を用いたシミュレーションは本震と同じマグ ニチュード M と震源距離 X を用いて前節で説明した統計的経時特性 モデルとスペクトルモデルから作成される。半経験的波形合成法に

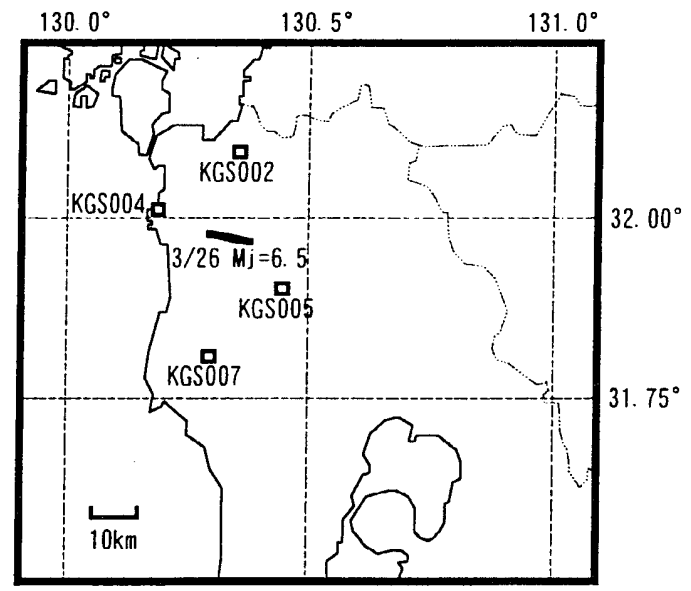

図 3 鹿児島県北西部地震の震源断層と解析地点の位置

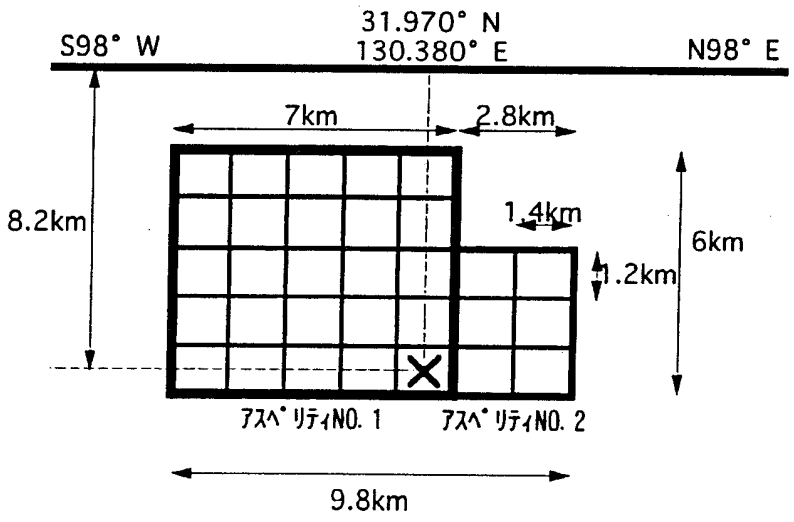

図 4 三宅ら (1999)による鹿児島県北西部地震の断層モデル

表 1 解析に用いたパラメター

\begin{tabular}{|c|c|c|}
\hline パラメター & Asperity No. 1 & Asperity No.2 \\
\hline 長さ $\mathrm{L} \times$ 幅 & $7[\mathrm{~km}] \times 6[\mathrm{~km}]$ & $2.8[\mathrm{~km}] \times 3.6[\mathrm{~km}]$ \\
\hline 走向 $\theta$, 傾斜角 $\delta$ & $98^{\circ}, 90^{\circ}$ & $98^{\circ}, 90^{\circ}$ \\
\hline S波速度 $\mathrm{Vs}$ & $3.1[\mathrm{~km} / \mathrm{s}]$ & $3.1[\mathrm{~km} / \mathrm{s}]$ \\
\hline 破壊伝播速度 $\mathrm{Vr}$ & $2.5[\mathrm{~km} / \mathrm{s}]$ & $2.5[\mathrm{~km} / \mathrm{s}]$ \\
\hline 立ち上がり時間 $\tau$ & $0.5[\mathrm{sec}]$ & $0.5[\mathrm{sec}]$ \\
\hline 破壊伝播様式 & Radial & Radial \\
\hline 重ね合わせ数 $\mathrm{N} \times \mathrm{N} \times \mathrm{N}$ & $5 \times 5 \times 5$ & $2 \times 3 \times 5$ \\
\hline 応力降下量の比 $\mathrm{C}$ & 1.06 & 0.70 \\
\hline
\end{tabular}

は Irikura ${ }^{2)}$ 改良した入倉ら ${ }^{13)}$ の手法を用いる。解析に用いた断 層モデルを図 4 に示す。このモデルは、震源の西側の大きなアスペ リティ(No.1) と東側の小さなアスペリティ(№.2)から成っており、 経験的グリーン関数法を用いたシミュレーションから三宅ら ${ }^{14)}$ が 推定したものである。断層パラメターを表 1 に示す。三宅ら ${ }^{14)}$ によ ると、小地震の重ね合わせは西側のアスペリティで $5 \times 5 \times 5$ 、東側 で $3 \times 2 \times 5$ であり、応力降下量の比 C をそれぞれ $1.06,0.70$ として いる。2. で示した統計的グリーン関数法を用いる場合、重ね合わ せ数を表す相似比 $\mathrm{N}$ はマグニチュードと地震モーメントの関係から 計算できるが、応力降下量はパラメターではないので $\mathrm{C}$ を厳密に設 定するのは難しい。ここでは、三宅ら ${ }^{14)}$ の評価に合わせ、まずマグ ニチュードM=4.7 として余震と同じ規模の統計的グリーン関数を作 成し、三宅ら ${ }^{14)}$ が推定した C をそのまま大地震動の合成に用いるこ とにした。統計的グリーン関数は各アスペリティごとにアスペリテ 1の中心と観測点間の距離を回㷌式の震源距離として作成する。 

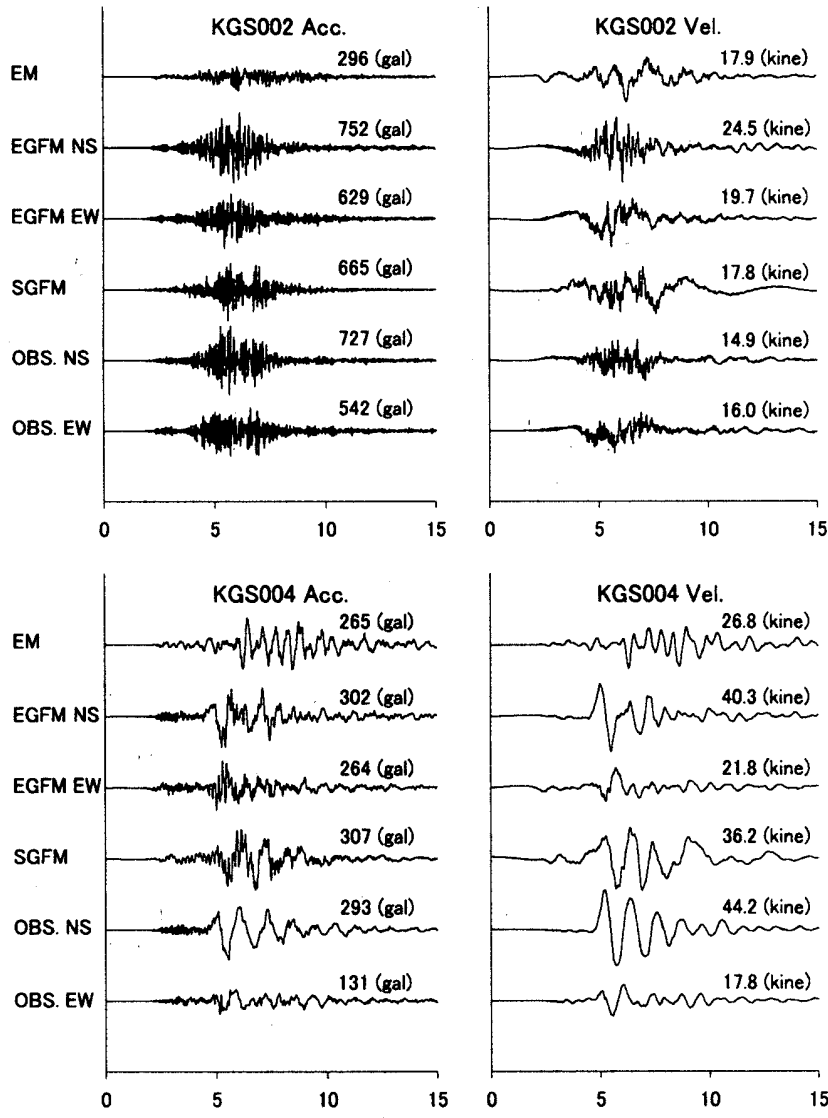

図 5 従来の経験的手法 (最上段)、 統計的グリーン関数法 (四段目) と敏測記録 (五段目と最下段) の比較
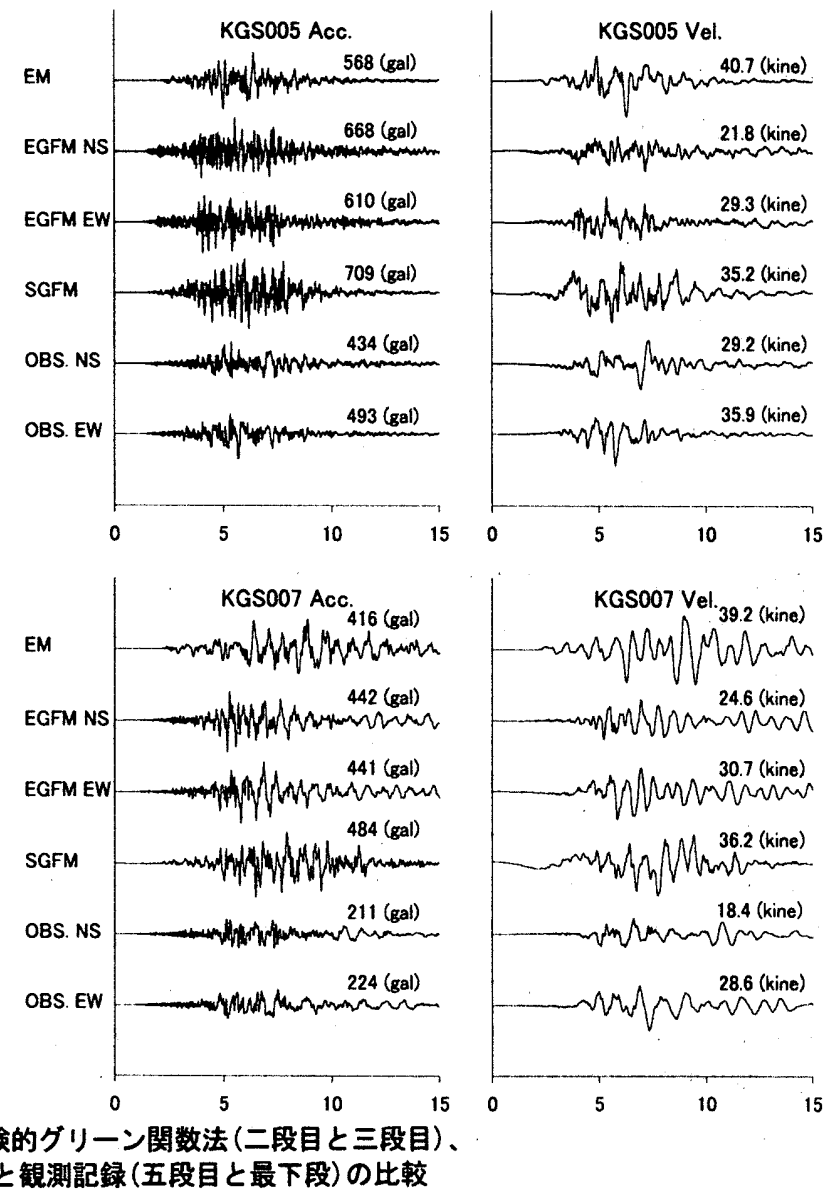

\section{2 解析結果}

図 5 に解析結果を示す。最上段が回帰式をそのまま用いた経験的 手法(EM)、二段目および三段目が経験的グリーン関数法 (EGFM NS, EGFM EW)、四段目が統計的グリーン関数法(SGFM)、五段目と最下段 が観測記録 (OBS. NS，OBS. EW) で左列に加速度波形、右列にそれを積 分した速度波形を示している。特に注目すべきは KGS004(阿久根)の 解析結果である。阿久根では周期 1 秒程度のやや短周期パルス波が 明瞭に観測されているが、従来の経験的手法(EM)ではこのパルス波 を再現できていない。図 6 の上に阿久根の観測スペクトル、下に各 シミュレーション波のスペクトルを示すが、経験的手法(EM)が 1.5 〜 $2 \mathrm{~Hz}$ 付近にピークがあるのに対し、観測スペクトルでは $0.5 \sim 1 \mathrm{~Hz}$ 付近にピークが見られる。一方、統計的グリーン関数法(SGFM)や経 験的グリーン関数法 (EGFM) では観測記録に見られるやや短周期パル ス波をうまくシミュレートできている。図 6 のスペクトルでも観測 と同じ $0.5 \sim 1 \mathrm{~Hz}$ 付近にピークが見られる。このや短周期パルス波 については液状化の影響と推定している報告 ${ }^{15)}$ もる。しかし、地 盤の線形性を仮定する波形合成法を用いてこのパルス波が再現でき ていること、また阿久根が西側の大きなアスペリティの破壊進行方 向に位置していることを考えると、これは液状化の影響というより もむしろ破壊伝播によるディレクティビティの影響が表れているも のと思われる。ただし、6Hz に見られるピークは観測にはほとんど 見られず、最表層（厚さ $5 \mathrm{~m}, V \mathrm{~s}=120 \mathrm{~m} / \mathrm{s}$ ) は非線形化していた可能性 が高い。これに対しKGS002(出水)，KGS005(宮之城)，KGS007(川内) については各手法とも観測記録と比べて、加速度レベルは過大評価 気味だが、全体的に概ね調和的な結果が得られている。これらの結 果は、破壊伝播によるディレクティビティの影響が大きい阿久根の
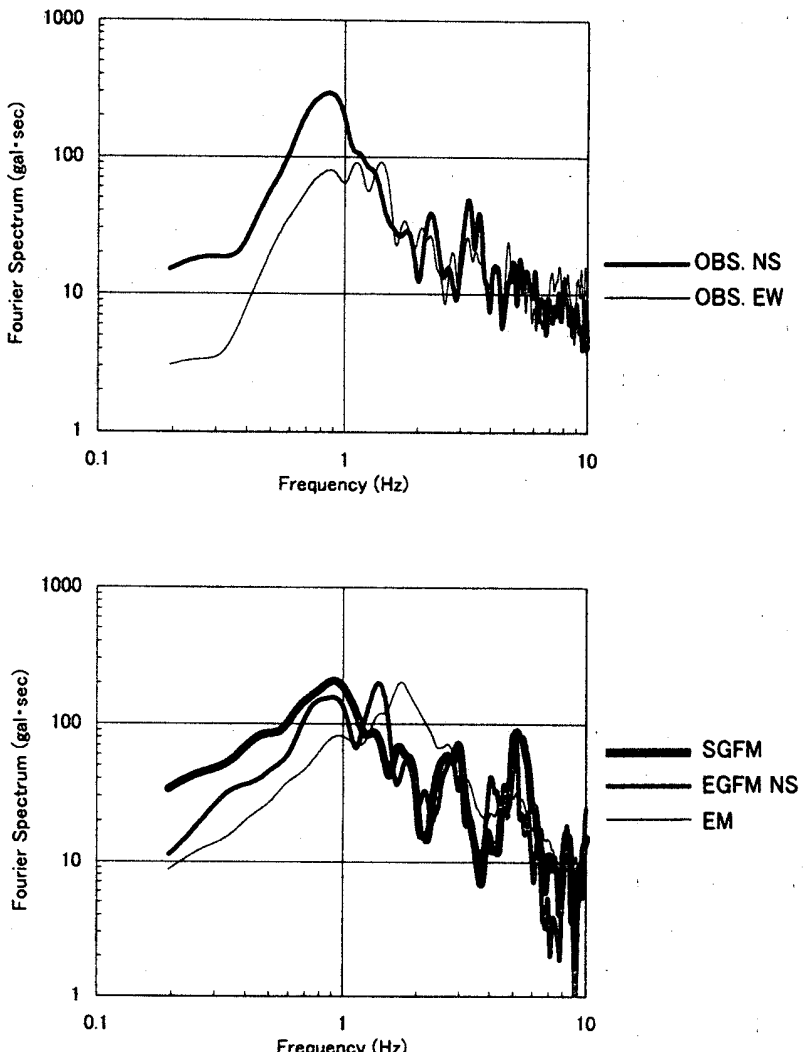

图 6 KGSO04(阿久根)の翻測スペクトル(上)と 各シミュレーション波のスペクトル(下)

ような場所では、点霞源を仮定した従来型の経験的方法では限界が あり、断層モデルに基づいた統計的グリーン関数法や経験的グリー ン関数法が必要であることを示している。 
次に、統計的グリーン関数を作成する際に与えるランダム位相の 影響を調べるために、異なる 20 個のランダム位相を用いて統計的グ リーン関数法によるシミュレーションを行い、最大值の平均 $\mathrm{m}$ と標 淮偏差 $\sigma$ を求めた。表 2 に結果を示す。これを見て分かるように与 えるランダム位相による影響はそれ程大きくなく、その標準偏差は 平均値の $15 \%$ 前後にとどまっている。

以上により、実際の中小地震観測記録を合成する経験的グリーン 関数法のみならず、経験的手法から得られる中小地震相当の模擬地 震動を合成する統計的グリーン関数法でも観測記録を再現すること に成功した。

\section{4. 兵庫県南部地震の強震動シミュレーション}

\section{1 断層モデルとパラメター}

ここでは統計的グリーン関数法を用いて 1995 年兵庫県南部地震 $(M j=7.2)$ の強震動シミュレーションを行う。兵庫県南部地震で注目 された、いわゆる「震災の帯」は、断層の破壊伝播によるディレク ティビティ効果と大阪盆地の深い盆地構造がもたらした「エッジ効 果」によるものと考えられている。ここでは、エッジ効果を含むサ イトの影響は別途考慮できるものとして第 2 節の基準観測点 ( 度 $1 \mathrm{~km} / \mathrm{sec}$ 相当)の基般スペクトルと基盤経時特性を用いて統計的 グリーン関数を作成し、基盤レベルの強震動シミュレーションを行 う。まず、破壊開始点を動かしながらパラメトリックスタディを行 い、基盤面最大速度分布がどのように変化するかを検討する。次に 露頭岩盤上と見なせる地点の観測記録とシミュレーション波を比較 し、統計的グリーン関数法の有用性を検証する。第 2 節の統計的性 質を抽出する際に我々が用いたデー夕は九州地方のものであるため、 これが関西地方の統計的性質と類似しているかどうかについて別途 検証する必要があるが、ここでは第一次近似としてそれが類似して いるものと仮定する。

断層モデルは、兵庫県南部地震 $(\mathrm{Mj}=7.2)$ の神戸側セグメントをモ デル化した松島・川瀬 "に従った。松島・川瀬 ”は波数積分法によ り計算された理論波形を用いて、観測波に見られる顕著な速度パル スが再現できるように、複数のアスペリティから成る断層モデルを フォワードインバージョンにより求めている。さらに、神戸市地域 の三次元盆地構造をモデル化し、三次元有限差分法を用いて強震動 シミュレーションを行った。推定された断層モデルは 4 つのアスペ リティから成り、経験的グリーン関数法を用いて兵庫県南部地震の 断層モデルを推定した釜江・入倉モデル ${ }^{16)}$ の改良版と言える。松 島・川瀬モデルの諸元を表 3 に、断層モデルを図 7 に示す。

波形合成に用いるパラメターは以下の手順で推定する。すでに述 べたように応力降下量の比 C は直接決定することはできないが、断 層全体の平均に対する各アスペリティごとの比として設定すること とした。つまり、用いた統計的グリーン関数はそもそも応力降下量 をパラメターとしていないので平均的には同じと見なしていること になるが、その平均からの相対的なずれをアスペリティごとに補正 したわけである。表 3 の各アスペリティのすべり量 $\mathrm{D}_{1} \sim \mathrm{D}_{4}$ と断層幅 $W_{1} \sim W_{4}$ を佐藤 ${ }^{17)}$ の応力降下量評価式、すなわち

$$
\Delta \sigma=\mathrm{a} \cdot \frac{\mu \mathrm{D}}{\mathrm{W}}
$$

に代入し、応力降下量 $\Delta \sigma_{1} \sim \Delta \sigma_{4}$ と平均的な応力降下量 $\Delta \sigma_{E}(=\Sigma$
表 2 統計的グリーン関数法による最大值のばらつき

\begin{tabular}{|c|c|c|c|c|c|}
\cline { 2 - 6 } \multicolumn{1}{c|}{} & 地点 & KGS002 & KGS004 & KGS005 & KGS007 \\
\hline \multirow{2}{*}{$\begin{array}{c}\text { 加速度 } \\
\text { (gal) }\end{array}$} & 平均值 $\mathrm{m}$ & 672.3 & 339.0 & 805.4 & 510.9 \\
\cline { 2 - 6 } & 標準偏着 $\sigma$ & 96.0 & 60.0 & 99.3 & 76.6 \\
\hline \multirow{2}{*}{$\begin{array}{c}\text { 速度 } \\
\text { (kine) }\end{array}$} & 平均值 $\mathrm{m}$ & 20.5 & 46.4 & 37.2 & 36.2 \\
\cline { 2 - 6 } & 標準偏差 $\sigma$ & 3.0 & 6.7 & 3.8 & 5.8 \\
\hline
\end{tabular}

$\left.\sigma_{\mathrm{i}} / 4\right)$ を求め、その比を各アスペリティの応力降下量の比 $\mathrm{C}_{1} \sim \mathrm{C}_{4}$ と する。ここで $\mu$ は断層を形成する媒質のせん断剛性率、a は断層面 の幾何学的形状や境界条件によって決まる定数である。次に佐藤 ${ }^{17)}$ のモーメント評価式(10)式を用いて統計的グリーン関数用地震のマ グニチュードを $\mathrm{M}=5$ と仮定しその地震モーメント $\mathrm{Mo}_{\mathrm{e}}$ を算定する。

$\log \mathrm{M}_{\mathrm{o}}($ dyne $\cdot \mathrm{cm})=1.5 \mathrm{M}+16.2$

最後に、表 3 に示す地震モーメント $\mathrm{Mo}_{1} \sim \mathrm{Mo}_{4}$ と応力降下量の比 $\mathrm{C}_{1} \sim$ $\mathrm{C}_{4}$ を用いて、横井・入倉 ${ }^{18)} の(11)$ 式から相似比 $\mathrm{N}_{1} \sim \mathrm{N}_{4}$ を求める。

$$
\mathrm{N}=\left(\frac{\mathrm{Mo}}{\mathrm{C} \cdot \mathrm{Mo}_{\mathrm{e}}}\right)^{\frac{1}{3}}
$$

これから要素サイズも決まる。立ち上がり時間は釜江・入倉 ${ }^{(6)}$ に従 い全アスペリティ $0.6 \mathrm{sec}$ とし、S 波速度は $3.5 \mathrm{~km} / \mathrm{sec}$ 、破壊伝播速 度は $3.0 \mathrm{~km} / \mathrm{sec}$ と仮定した。表 4 に解析に用いたパラメターを示す。

\section{2 解析結果}

はじめに破壊開始点の与える影響を調べるためにパラメトリック スタディを行った。破壊開始点を変化させた場合の基盤面最大速度 分布を図 8 に示す。松島・川瀬モデルでは、西側 3 つのアスペリテ イの傾斜角 (dip) は $90^{\circ}$ 、最も東側のアスペリティは傾斜角 (dip) を $85^{\circ}$ としているが、パラメトリックスタディでは 4 つのアスペリ ティは全て傾斜角 $90^{\circ}$ とした。また、各アスペリティの破壊は破壊

表 3 松島・川瀬モデルの各アスペリティの諸元

\begin{tabular}{|c|c|c|c|}
\hline Asperity No. & Mo $\times 10^{18}[\mathrm{Nm}]$ & Size $[\mathrm{km} 2]$ & すべり量D $[\mathrm{m}]$ \\
\hline 1 & 0.62 & $4.5 \times 5$ & 0.85 \\
\hline 2 & 1.07 & $4.5 \times 5$ & 1.47 \\
\hline 3 & 2.59 & $8 \times 10$ & 1.00 \\
\hline 4 & 4.83 & $8 \times 10$ & 1.90 \\
\hline
\end{tabular}

\begin{tabular}{c|c|c|c|c|c|}
\hline & \\
\hline
\end{tabular}


開始点に対して最短距離にある最深部のコーナーからラディアルに 進行していくものとした。即ち破壊開始点が A 点の場合、各アスペ リティの破壊は各々最西端深部から始まる。

A 点から破壊が進行する場合、大きなアスペリティと破壊伝播に よるディレクティビティの影響を強く受汁るアスペリティ No. 4 の 真上あるいは東側に速度の大きな領域が見られる。次に B, C が破壊 開始点の場合、アスペリティNo. 4 は最西端深部から破壊が進行する のでその影響はA 点の場合と変わらないが、その他のアスペリティ では破壊が最東端媣部から進行するために、西側に速度 10 $30 \mathrm{~m} / \mathrm{sec}$ の領域が広がった。D点の場合、アスペリティNo. 4 の破壊 も最東端樑部から進行するので、速度の大きな領域が $\mathrm{B}, \mathrm{C}$ 点の場合 よりさらに西側に広がるようになっている。このように破壊開始点 は基盤面最大速度分布に大きな影響を与えることが分かる。

次に、松島・川瀬モデルと同じく破壊開始点を $\mathrm{A}$ 点とした場合の 基盤面速度波形を兵庫県南部地震の際に観測された露頭岩盤相当の 観測記録と比較する。ここではアスペリティ No. 4 の傾斜角を $85^{\circ}$ とし、観測記録は断層直交方向に相当する $\mathrm{N} 33^{\circ}$ W 成分で表すこと にする。図 9 に解析地点を示す。解析地点は神戸大学 (KBU) と本山第 一小学校 (MOT) である。両地点とも断層の破壊進行方向に位置してお り、明瞭な速度パルスが観測されている。図 10 に解析結果を示す。 上段が統計的グリーン関数法を用いた合成波、下段が観測波 (N33 W 成分の速度波形)である。これを見て分かるように KBU, MOT とも観 測記録に見られるパルス波が再現できている。このことは、震源モ デルを的確に表現できれば、統計的グリーン関数法により強震動を 予測することが可能であることを示している。なお、ここでは放射 特性は考慮していないが、その周波数依存性が与えられれば考慮す ることは容易である。本手法を適用した場合、まず基盤面の合成波 形を計算し、次に基盤以浅の堆積層の影響について別途考虑するこ とになるが、神戸の場合のように地震基盤から上の堆積層の影響が 強い場合はその基盤の速度差を補正する必要がある。

\section{5. 仮想福岡地震の強震動予測}

\section{1 予测プロセス}

最後に福岡市直下の警固断層を対象に強震動予測を行う。統計的 グリーン関数法の大きな利点は、破壊伝播によるディレクティビテ

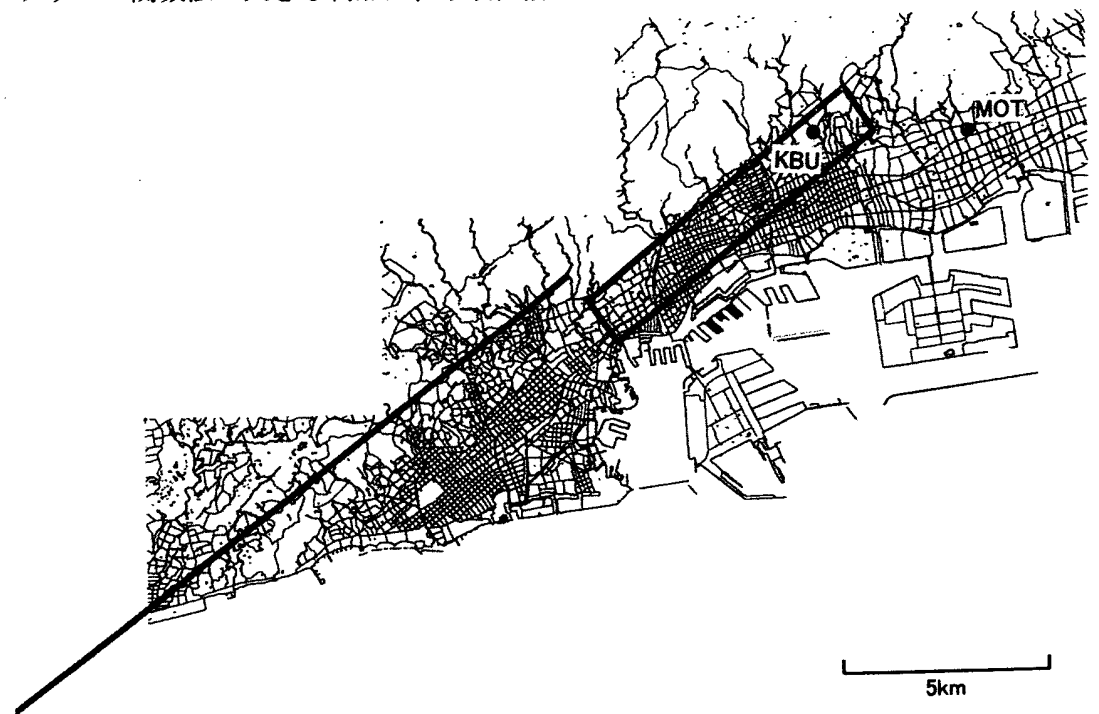

図 9 解析地点 $\square 0-15 \square 15-30 \div 30-45: 45-60=60-75$

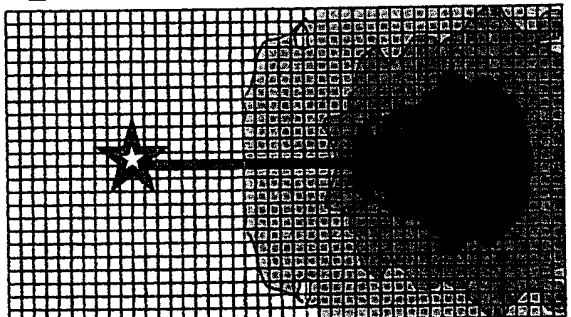

(a) $\mathrm{A}$ 点か破濖開始点の場合

$\square 0-15 \square 15-30=30-45=45-60=60-75$

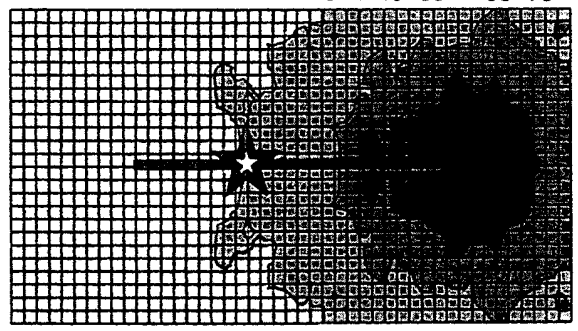

(b) B 点が破壊開始点の堨合

D0-15 $\square 15-30 \square 30-45 \square 45-60 \square 60-75$

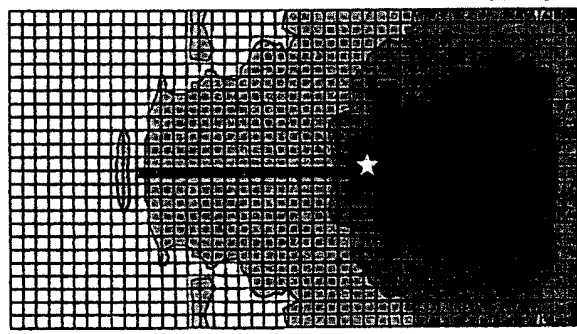

(c) C 点が破壊開始点の場合

$\square 0-15 \square 15-30 \square 30-45 \square 45-60 \square 60-75$

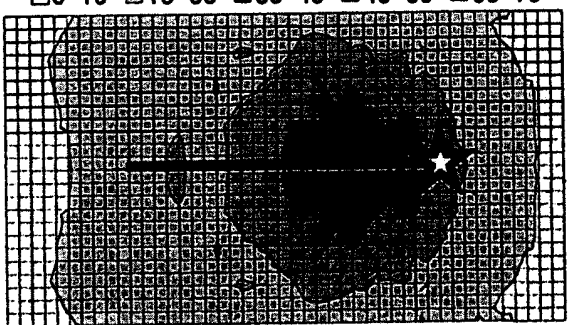

（d） D 点が破壊開始点の埥合

図 8 破罱開始点を变化させた場合の基盤面最大速度分布 $(\mathrm{cm} / \mathrm{sec})$ 


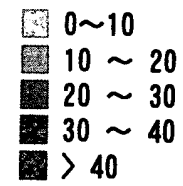

$10 \sim 20$
$20 \sim 30$

$30 \sim 40$

$>40$

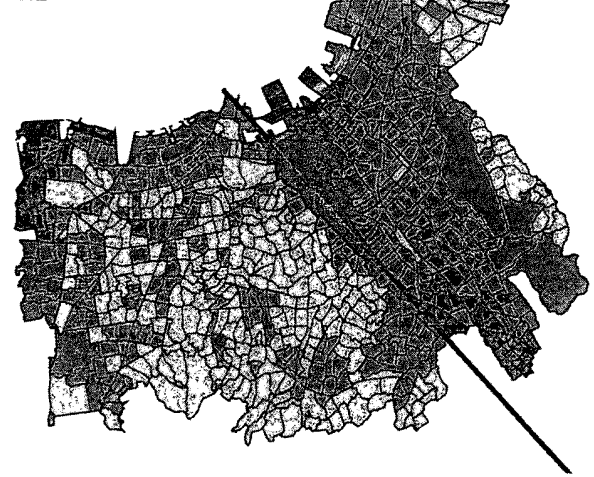

図 11 福岡市の $V_{s}=600 \mathrm{~m} / \mathrm{s}$ 層の深さマップ $(\mathrm{m})^{19}$

イ効果を表現できること、また地動最大值だけではなく建物の応答 解析に必要な合成波形が得られることである。ここでは対象とする 警固断層の地震像が明らかでないこと、また防災計画上これまで 我々が経験した最大級の内陸地震を想定すべきであることを考え、 兵庫県南部地震 $(M j=7.2)$ の神戸側セグメントと同じ規模の地震が発 生すると仮定する。警固断層は博多湾から福岡市の中心部を通り南 西方向人少なくとも約 $20 \mathrm{~km}$ 延びているが、本論では図 7 の断層モデ ルを警固断層に沿って D 点が博多湾側となるように配置した。なお、 福岡市における町丁目ごとの表層地盤による影響を反映した強震動 予測を行うため、まず地表面下に想定した基盤面 (S 波速度 $1 \mathrm{~km} / \mathrm{sec}$ ) における強震動を求め、次に各町丁目ごとの地盤特性を考慮して地 表面の強震動を予測するという二段階の手法を用いている。

\section{2 サイト特性の評価}

まず福岡地盤図 $\left.{ }^{19}\right)$ に基づいて各町丁目ごとの基盤梁さ ( $\mathrm{S}$ 波速度 約 $600 \mathrm{~m} / \mathrm{sec}$ ) を推定する。図 11 に福岡市の基盤深さマップを示す。 鳘固断層付近に基盤の深い地域が見られることが分かる。次に我々 が収集した福岡市内の 33 本のPS 検層データに基づき、平均的な 4 層モデル $\left(V_{S}=200,400,600,1000 \mathrm{~m} / \mathrm{sec}\right)$ を仮定する。各層の深さは $\mathrm{V}_{\mathrm{s}}=600 \mathrm{~m} / \mathrm{sec}$ の層染さに対する比として求められており、図 11 に示 す基盤染さにこの層厚比を掛けあわせて町丁目ごとに地盤構造が推 定される。そして得られた各町丁目の地盤構造から一次元重複反射 理論を用いてサイト特性を評価することにした。

統計的スペクトル特性を求める際に分離された FK0006(福岡市) のサイト特性 $10^{(\mathrm{j} \text { (f) } \mathrm{f})-\mathrm{cl}(\mathrm{f})}$ とこの観測点のある町丁目の基盤梁さから 推定された一次元重複反射理論による理論值の比較を図 12 に示す。 図の右にはモデル化した地盤構造も示した。Q值は一律 25 としてい る。分離により得られたサイト特性と理論值の一次ピークが良く対 応していることが分かる。ただ低周波数領域では分離により得られ たサイト特性が理論值よりも若干大きくなっている。これは分離さ れた観測サイト特性には表面波の混入があるのに、理論值には含ま れていないためと思われる。

表層地盤モデルに基づいた理論増幅特性による評価法の有効性 を検証するために FK0006 について 1999 年 3 月 9 日に熊本県阿蘇地 方で発生した地震 $(M j=4.5)$ を対象に統計的グリーン関数を作成した。 まず基盤スペクトルと基盤経時特性を用いて統計的グリーン関数を

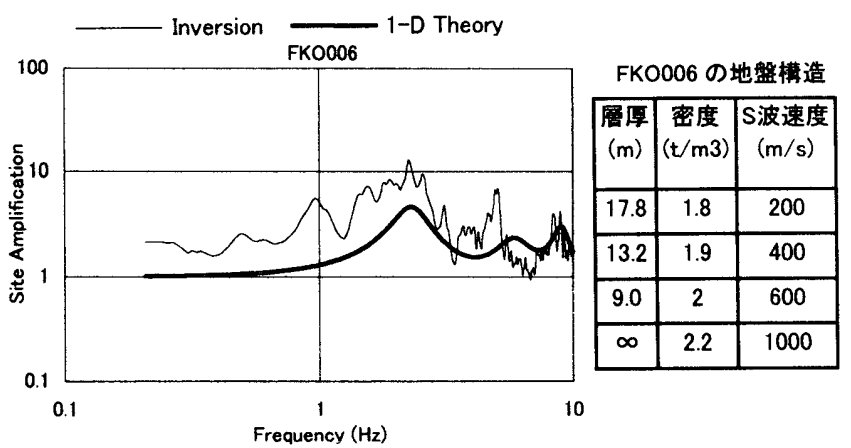

图 12 インパージョンにより得られたサイト特性と 一次元重複反射理論による理論値の比較
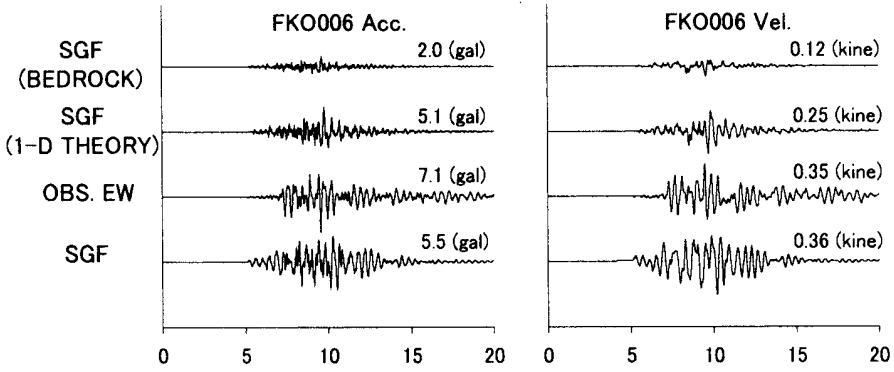

図 13 基盤面の統計的グリーン関数 (最上段)および一次元波動論から 得られた地表面の統計的グリーン関数 (二段目) と覾測記録 (三段目) および分離されたサイト特性を用いた統計的グリーン関数 (最下段)
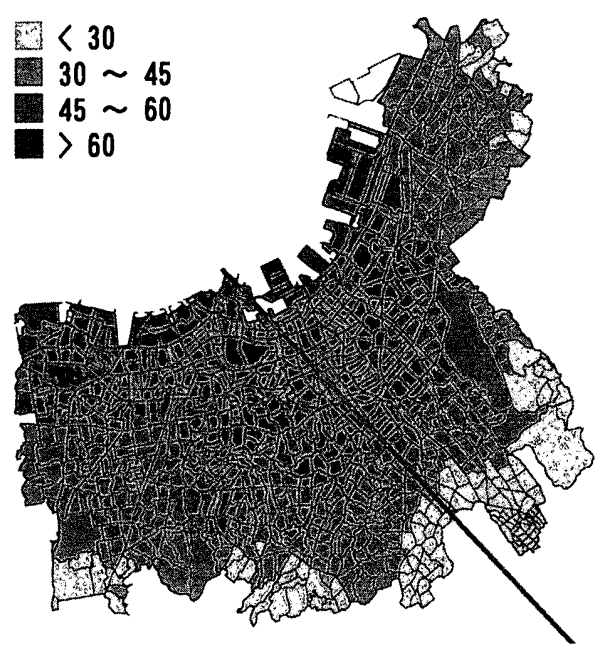

図 14 福岡市の基盤面最大速度マップ $(\mathrm{cm} / \mathrm{sec})$
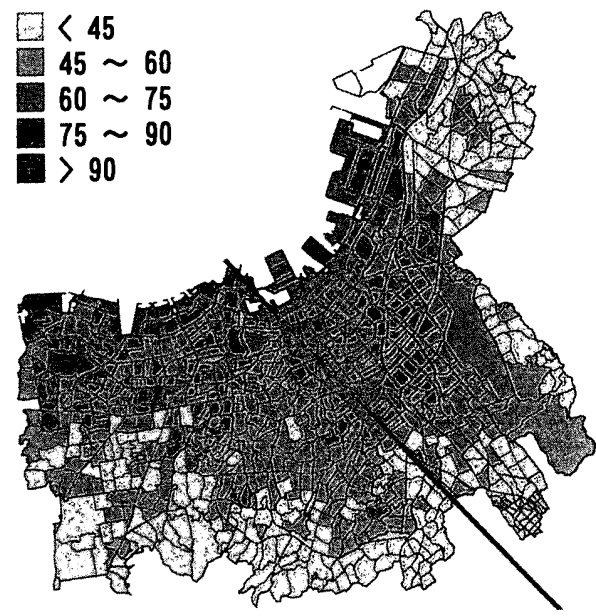

図 15 福岡市の地表面最大速度マップ $(\mathrm{cm} / \mathrm{sec})$ 
作成し、図 12 に示したFK0006 の理論增幅特性を考慮して地表面に おける統計的グリーン関数を求めた。図 13 の最上段にFK0006の基 盤面におう統計的グリーン関数(SGF (Bedrock))を、二段目および 三段目に地表面の統計的グリーン関数 (SGF(1-D Theory)) と観測記 録 (OBS. EW) を比較して示す。最上段に示す基盤波が一次元波動論を 用いて理論的に計算されたサイト特性の影響で増幅され、観測記録 に概ね一致した波形と最大值が得られていることが分かる。このこ とは K-net 観測点以外の地点においても、まず基盤スペクトルと基 盤経時特性を用いて統計的グリーン関数を作成し、別途得られた理 論増幅特性を用いて、地表面における統計的グリーン関数を作成す ることが可能であることを示している。ただしFKS006 ではこの観測 点のサイト係数を用いた場合 (SGF) と比べると地盤モデルを用いた 場合は過小評価気味で、図 12 のスペクトルの差を反映している。

\section{3 強震動予測}

図 14 に図 $8(\mathrm{a})$ と同じく $\mathrm{A}$ 点を破壊開始点とし南から北に破壊さ せた場合の基盤面上の予測最大速度マップを示す。福岡市の中心部 から破壊の進行方向に沿って、基盤面最大速度 $50 \sim 60 \mathrm{~cm} / \mathrm{sec}$ の領域 が分布しており、ディレクティビティ効果を反映した結果が得られ ている。次に各町丁目ごとに一次元重複反射理論を用いて地表面に おける強震動を計算する。図 15 に表層地盤の影響を考慮した地表面 上の予測最大速度マップを示す。福岡市では最大で $100 \mathrm{~cm} / \mathrm{sec}$ 程度 の最大速度が予測され、市中心部で大きな被害が予想される結果と なった。ただ、これは兵庫県南部地震の「震災の帯」内の推定最大 速度レベル ${ }^{1)}$ と比べると小さい。これは、ひとつにはやや短周期域 のサイト特性を過小評価しているためである。また放射特性の評価 が入っていないことの影響もあろう。なお、破壊開始点を変えた場 合や破壊進行方向を変えたケースも検討しているがいずれの場合も 福岡市内の最大速度は図 15 と同程度かそれ以下となった。

\section{6. まとめ}

本研究では、九州地方の K-net 観測記録から抽出した地震動の統 計的性質を用いて、統計的グリーン関数法による強震動予測法の検 証を行い、本手法を福岡市直下の警固断層に適用した。まず 1997 年の鹿児島県北西部地震の強震動シミュレーションを行い、従来型 の経験的な強震動予測手法と比較して統計的グリーン関数法の有用 性を確認した。特に、破壊伝播によるディレクティビティ効果が大 きい地点では断層モデルを考虑した強震動予測が必要であることが 示された。次に基盤における統計的グリーン関数を用いて 1995 年の 兵庫県南部地震の強震動シミュレーションを行った。破壊開始点を 変化させたパラメトリックスタディを行い、基盤面最大速度分布が どのように変化するかについて考察するとともに、露頭岩盤と見な せる神戸大学 $(\mathrm{KBU})$ や本山第一小学校 (MOT)の観測記録と本震と同じ 破壊開始点を用いた合成波を比較した。合成波は観測波のパルスを うまく再現しており、断層モデルさえ適切に表現すれば基盤上の強 震動予測が可能であることが分かった。そして最後に、警固断首で 兵庫県南部地震の神戸側セグメントと同じ規模の地震が発生した際 の強震動予測を行った。ここではまず基盤面における強震動を求め、 さらに実際の基盤深さに基づいた地盤増幅特性を考虑して地表面の 強震動を予測した。福岡市では最大で $100 \mathrm{~cm} / \mathrm{sec}$ 程度の最大速度が 予測されたが、兵庫県南部地震の推定最大速度レベルに比べると小
さいものであった。その原因については今後定量化したい。

本研究の強震動予測プロセスを用いれば日本全国で震源とサイト の影響を考慮した定量的強震動予測が可能となるが、地盤の非線型 化の影響などについては別途考慮する必要がある。また防災計画を 考える上では、実在する建物群と強震動レベルから地震被害予測を 行うことも重要となる。これらについては今後の検討課題である。

\section{謝辞}

本研究には科学技術庁防災科研の強震観測網 K-net のデータを利 用させて頂きました。また九州大学大学院修士課程久原寛之君には 図面の作成などに協力頂きました。ここに哚く感謝いたします。

参考文献

1）松島信一・川瀬博, 1995 年兵庫県南部地震の複数アスペリティモデルの提 案とそれによる強震動シミュレーション, 日本建築学会構造系論文集，第 534 号, 33-40, 2000.8.

2) Irikura, K., Prediction of strong acceleration motions using empirical Green's function, Proc. 7th Japan Earthq. Eng. Symp., 151-156, 1986.

3）坖江克芸・入倉孝次郎・福知保長, 地震のスケーリング則に基づいた大地 震時の強震動予測：統計的波形合成法による予測，日本建築学会樓造系論 文集, 第 430 号, 1-9, 1991.2.

4) Aki, K., Scaling law of seismic spectrum, J. Geophys. Res., Vol. 72, No. 4, 1217-1231, 1967.

5) Boore, D. M. , Stochastic simulation of high frequency ground motions based on seismological models of the radiated spectra, Bull. Seism. Soc. Am., Vol. 73, No. 6, 1865-1894, 1983.

6）壇一男 - 渡辺基史 ·佐藤俊明 - 宮腰淳一・佐藤智美, 統計的グリーン関数 による 1923 年関東地震 (M jma7.9) の広域強震動評価, 日本建築学会構造系 論文集，第 530 号，53-62，2000. 4.

7）佐藤智美・川瀬博・佐藤俊明，観測記録から同定した地震動の統計的性質 と地盤の非線型性を考滵した強震動予測、日本建築学会構造系論文集，第 463 号, 27-37, 1994.9.

8）佐藤智美・川瀬博・佐藤俊明，ボアホール観測記録を用いた表層地盤同定 手法による工学的基盤波の推定及びその統計的経時特性, 日本建築学会構 造系論文集, 第 461 号, 19-28, 1994.7.

9）佐藤智美・川瀬博・佐藤俊明，表層地盤の影響を取り除いた工学的基盤波 の統計的スペクトル特性:仙台地域のボアホールで観測された多数の中小 地震記録を用いた解析, 日本建築学会構造系論文集, 第 462 号, 79-89, 1994.8.

10) 伊藤茂郎・久原寛之・川瀨博, K-NET 強震観測記録を用いた九州地方の統 計的地震動特性 : その 1. 地震動の統計的経時特性, 日本建築学会九州支部 研究報告, 269-272, 2000.3.

11）久原寛之・伊藤茂郎・川瀬博，K-NET 強震観測記録を用いた九州地方の統 計的地震動特性 : その 2. 地震動の統計的スペクトル特性, 日本建築学会九 州支部研究報告, 273-276, 2000.3.

12）墒一男・宮脇淳一・八代和彦，中規模地震の観測記録から得られる地盤增 幅特性に基づく大規模地震の応答スペクトルの简易評価法, 日本建築学会 構造系論文集，第 480 号，35-46，1996.2.

13）入倉孝次郎・香川敬生・関口春子, 経験的グリーン関数法を用いた強震動 予測方法の改良, 日本地震学会講演予稿集, No. 2, B25, 1997. 10.

14) 三宅弘恵・岩田知孝・入倉孝次郎，経験的グリーン関数法を用いた 1997 年 3 月 26 日 $\left(\mathrm{M}_{\mathrm{JMA}} 6.5\right)$ 及び 5 月 13 日 $\left(\mathrm{M}_{\mathrm{SMA}} 6.3\right)$ 鹿児島県北西部地震の強震動 シミュレーションと震源モデル, 地震第 2 輯, 第 51 巻, 第 4 号, 431-442, 1999.

15)松村和雄, 1997 年鹿児島県北西部地震の地慜動の特性, 日本建築学会構造 系論文集，第 512 号，75-82，1998.10.

16）釜江克宏・入倉孝次郎，1995 年兵庫県南部地震の断層モデルと震源近傍に おける強震動シミュレーション, 日本建築学会構造系論文集, 第 500 号, 29-36, 1997. 10 .

17)佐藤良輔 編著, 日本の地震断層パラメター・ハンドブック，鹿島出版会， 1989.

18)横井俊明・入倉孝次郎, 震源スペクトルのScaling 則と経験的 Green 関数 法，地震第 2 輯，第 44 巻，第 2 号，109-122，1991.

19）九州地質調查業協会, 福岡地盤図, 1981 